\title{
Infrared Spectra and X-ray Examination of the Complex Albumin Human with $\mathrm{UO}_{2}{ }^{2+}$
}

\author{
Aibassov Yerkin Zhakenovich ${ }^{1 *}$, Yemelyanova Valentina ${ }^{1}$, Shakieva Tatyana ${ }^{1}$, Nakisbekov Narymzhan ${ }^{2}$, \\ Tussupbaev Nessipbay ${ }^{1}$, Abenov Bakhyt ${ }^{1}$, Bulenbayev Maxat ${ }^{1}$, Dossumova Binara ${ }^{1}$ and Blagikh Evgeniy ${ }^{1}$ \\ 1. Research Institute of New Chemical Technologies and Materials, Kazakh National University Al-Farabi, Almaty 005012, Kazakhstan \\ 2. Institute of Fundamental and Applied Medicine, Kazakh National Medical University, Almaty 005012, Kazakhstan
}

Abstract: Reaction dioxouraniun (VI) $\mathrm{UO}_{2}{ }^{2+}$ ion with human serum albumin was prepared: human albumin with uranium $\mathrm{UO}_{2}{ }^{2+}$ ion and the X-ray method of investigation of these complexes. The authors have shown that Human Albumin may be used to remove highly toxic uranyl $\mathrm{UO}_{2}{ }^{2+}$ ions.

Key words: Albumin serum human, dioxouraniun (VI) $\mathrm{UO}_{2}{ }^{2+}$ ion, X-ray, complex.

\section{Introduction}

Human serum albumin is the most abundant protein in human blood plasma. It is produced in the liver. Albumin constitutes about half of the blood serum protein. It is soluble and monomeric. Albumin transports hormones, fatty acids, and other compounds, buffers $\mathrm{pH}$, and maintains osmotic pressure, among other functions. Albumin is synthesized in the liver as a prealbumin, which has an N-terminal peptide, which is removed before the protein is released from occurring rough endoplasmic reticulum human. The product, proalbumin, is in turn cleaved in the Golgi vesicles to produce the secreted albumin.

The approximate sequence of human serum albumin is:

$\begin{array}{ccc}\text { MKWVTFISLL } & \text { FLFSSAYSRG } & \text { VFRRDAHKSE } \\ \text { VAHRFKDLGE } & \text { ENFKALVLIA } & \text { FAQYLQQCPF } \\ \text { EDHVKLVNEV } & \text { TEFAKTCVAD } & \text { ESAENCDKSL } \\ \text { HTLFGDKLCT } & \text { VATLRETYGE } & \text { MADCCAKQEP } \\ \text { ERNECFLQHK } & \text { DDNPNLPRLV } & \text { RPEVDVMCTA } \\ \text { FHDNEETFLK } & \text { KYLYEIARRH } & \text { PYFYAPELLF } \\ \text { FAKRYKAAFT } & \text { ECCQAADKAA } & \text { CLLPKLDELR }\end{array}$

*Corresponding author: Aibassov Yerkin Zhakenovich, professor, research field: organic chemistry of $\mathrm{U}, \mathrm{Th}, \mathrm{As}, \mathrm{Sb}$, Bi. E-mail: erkin53@mail.ru.

$\begin{array}{lcr}\text { DEGKASSAKQ } & \text { RLKCASLQKF } & \text { GERAFKAWAV } \\ \text { ARLSQRFPKA } & \text { EFAEVSKLVT } & \text { DLTKVHTECC } \\ \text { HGDLLECADD } & \text { RADLAKYICE } & \text { NQDSISSKLK } \\ \text { ECCEKPLLEK } & \text { SHCIAEVEND } & \text { EMPADLPSLA } \\ \text { ADFVESKDVC } & \text { KNYAEAKDVF } & \text { LGMFLYEYAR } \\ \text { RHPDYSVVLL } & \text { LRLAKTYETT } & \text { LEKCCAAADP } \\ \text { HECYAKVFDE } & \text { FKPLVEEPQN } & \text { LIKQNCELFE } \\ \text { QLGEYKFQNA } & \text { LLVRYTKKVP } & \text { QVSTPTLVEV } \\ \text { SRNLGKVGSK } & \text { CCKHPEAKRM } & \text { PCAEDYLSVV } \\ \text { LNQLCVLHEK } & \text { TPVSDRVTKC } & \text { CTESLVNRRP } \\ \text { CFSALEVDET } & \text { YVPKEFNAET } & \text { FTFHADICTL } \\ \text { SEKERQIKKQ } & \text { TALVELVKHK } & \text { PKATKEQLKA } \\ \text { VMDDFAAFVE } & \text { KCCKADDKET } & \text { CFAEEGKKLV } \\ \text { AASQAALGL. } & & \end{array}$

The italicized first 24 amino acids are signal and propeptide portions are not observed in the translation, and transported protein but present in the gene. There are 609 amino acids in this sequence with only 585 amino acids in the final product observed in the blood.

In work [1] has been studied chemical and biological insights into uranium-induced apoptosis of rat hepatic cell line. Uranium release into the environment is a threat to human health, and the mechanisms of cytotoxicity caused by uranium are not well-understood. To improve our understanding in this respect, the authors herein evaluate the effects of 
uranium exposure on normal rat hepatic BRL cells. As revealed by SEM (scanning electron microscopy) and TEM (transmission electron microscope) analyses, uranyl nitrate was found to be transformed into uranyl phosphate particles in the medium and taken up by BRL cells in an endocytotic uptake manner, which presumably initiates apoptosis of the cell, although soluble uranyl ion may also be toxic. The apoptosis of BRL cells upon uranium exposure was also confirmed by both the acridine orange and ethidium bromide double staining assay and the Annexin V/propidium iodide double staining assay. Further studies revealed that uranium induced the loss of mitochondrial membrane potential in a dose-dependent manner. Moreover, the uranium-induced apoptosis was found to be associated with the activation of caspase-3, caspase- 8 and caspase-9, indicating both a mitochondria-dependent signaling pathway and a death receptor pathway by a crosstalk. This study provides new chemical and biological insights into the mechanism of uranium toxicity toward hepatic cells, which will help seek approaches for biological remediation of uranium.

\section{Experimental Sections}

Dioxouranium (VI) $\left(\mathrm{UO}_{2}{ }^{2+}\right)$ cation was used as nitrate salts. Albumin human was used as disodium salt. Reaction dioxouraniun (VI) $\mathrm{UO}_{2}{ }^{2+}$ ion with human serum albumin was prepared: human albumin with uranium $\mathrm{UO}_{2}{ }^{2+}$ ion and the X-ray method of investigation of these complexes.

\section{Results and Discussion}

In work [1] has been studied structural consequences of Binding of $\mathrm{UO}_{2}{ }^{2+}$ to Apotransferrin.

It has been established that transferrin binds a variety of metals. These include toxic uranyl ions which form rather stable uranyl-transferrin derivatives. The authors determined the extent to which the iron binding sites might accommodate the peculiar topographic profile of the uranyl ion and the consequences of its binding on protein conformation. Indeed, metal intake via endocytosis of the transferrin/transferring receptor depends on the adequate coordination of the metal in its site, which controls protein conformation and receptor binding. Using UV-vis and Fourier transform infrared difference spectroscopy coupled to a microdialysis system, the authors showed that at both metal binding sites two tyrosines are uranyl ligands, while histidine does not participate with its coordination sphere. Analysis by circular dichroism and DSC (differential scanning calorimetry) showed major differences between structural changes associated with interactions of iron or uranyl with apotransferrin. Uranyl coordination reduces the level of protein stabilization compared to iron, but this may be simply related to partial lobe closure. The lack of interaction between
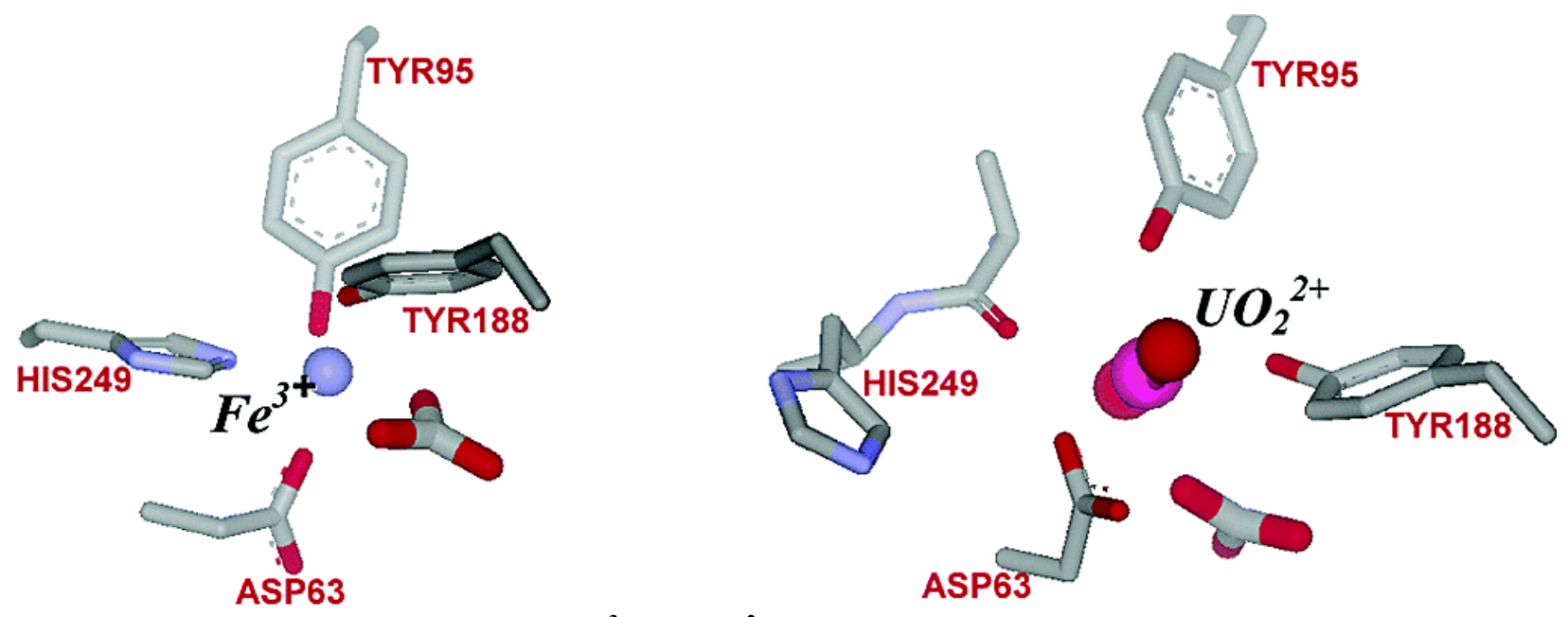

Fig. 1 Structural consequences of binding of $\mathrm{Fe}^{3+}$ and $\mathrm{UO}_{2}{ }^{2+}$ to Apotransferrin. 
uranyl-TF and its receptor was shown by flow cytometry using Alexa 488-labeled holotransferrin. The authors propose a structural model summarizing our conclusion that the uranyl-TF complex adopts an open conformation that is not appropriate for optimal binding to the transferrin receptor.

In work [2] has been studied $\mathrm{UO}_{2}{ }^{2+}$ uptake by proteins. The capture of uranyl, $\mathrm{UO}_{2}{ }^{2+}$, by a recently engineered protein with high selectivity and femtomolar sensitivity has been examined by a combination of density functional theory, molecular dynamics, and free-energy simulations. It was found that $\mathrm{UO}_{2}{ }^{2+}$ is coordinated to five carboxylate oxygen atoms from four amino acid residues of the SUP (super uranyl binding protein). A network of hydrogen bonds between the amino acid residues coordinated to $\mathrm{UO}_{2}{ }^{2+}$ and residues in its second coordination sphere also affects the protein's uranyl binding affinity. Free-energy simulations show how $\mathrm{UO}_{2}{ }^{2+}$ capture is governed by the nature of the amino acid residues in the binding site, the integrity and strength of the second-sphere hydrogen bond network, and the number of water molecules in the first coordination sphere. Alteration of any of these three factors through mutations generally results in a reduction of the binding free energy of $\mathrm{UO}_{2}{ }^{2+}$ to the aqueous protein as well as of the difference between the binding free energies of $\mathrm{UO}_{2}{ }^{2+}$ and other ions $\left(\mathrm{Ca}^{2+}, \mathrm{Cu}^{2+}, \mathrm{Mg}^{2+}\right.$, and $\mathrm{Zn}^{2+}$ ), a proxy for the protein's selectivity over these ions. The results of the free-energy simulations confirmed the previously reported experimental results and allowed us to discover a mutant of SUP, specifically the GLU64ASP mutant, that not only binds $\mathrm{UO}_{2}{ }^{2+}$ more strongly than SUP but that is also more selective for $\mathrm{UO}_{2}{ }^{2+}$ over other ions. The predictions from the computations were confirmed experimentally [3-5].

Analysis of the complex albumin human with uranium $\mathrm{UO}_{2}{ }^{2+}$ ion was performed by X-ray microanalysis. Instrument: electron probe microanalyzer. Brand: Superprobe 733, Japan Electron Optics Laboratories, Japan.

The analysis of the elemental composition of the resulting of the microsphere magnetic catalyst with salts of Thorium and Uranium was performed using energy-dispersive spectrometer Energy Oxford Instruments, England, established by electron probe microanalyzer Superprobe 733 at an accelerating voltage of $25 \mathrm{kV}$ and a probe current of $25 \mathrm{nA}$.

Figs. 2 and 3 show the laboratory unit and X-ray spectrum of the complex albumin human with $\mathrm{UO}_{2}{ }^{2+}$.

Table 1 shows the elemental composition of the complex albumin human with $\mathrm{UO}_{2}{ }^{2+}$ ion.

Fig. 4 shows IR spectrum of the complex albumin human with $\mathrm{UO}_{2}{ }^{2+}$.

Thus, the authors obtained a complex of albumin human with uranium $\mathrm{UO}_{2}{ }^{2+}$ ions and IR spectra and $\mathrm{X}$-ray method to explore these complexes.

\section{Conclusions}

Interaction of dioxouraniun (VI) $\mathrm{UO}_{2}{ }^{2+}$ ion with albumin human was obtained a complex of adenosine with uranium $\mathrm{UO}_{2}{ }^{2+}$ ion and X-ray method to explore these complexes. 


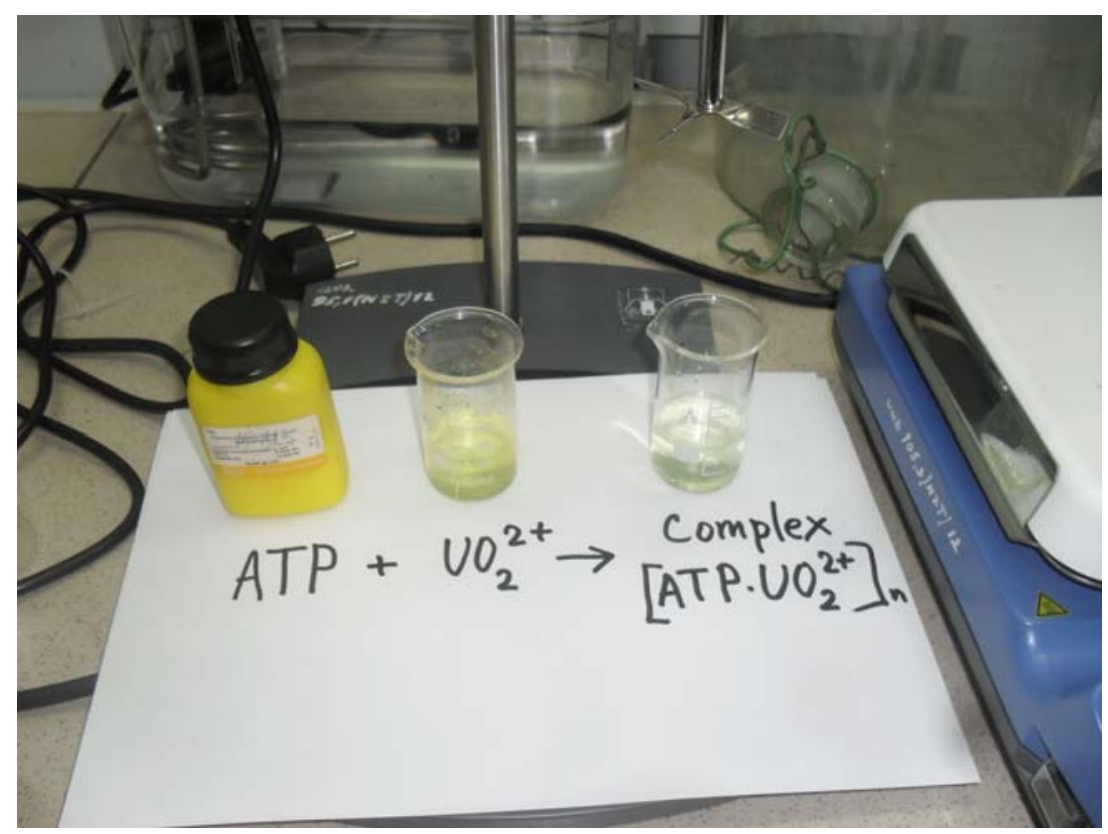

Fig. 2 Obtain a complex of albumin human with $\mathrm{UO}_{2}{ }^{2+}$.

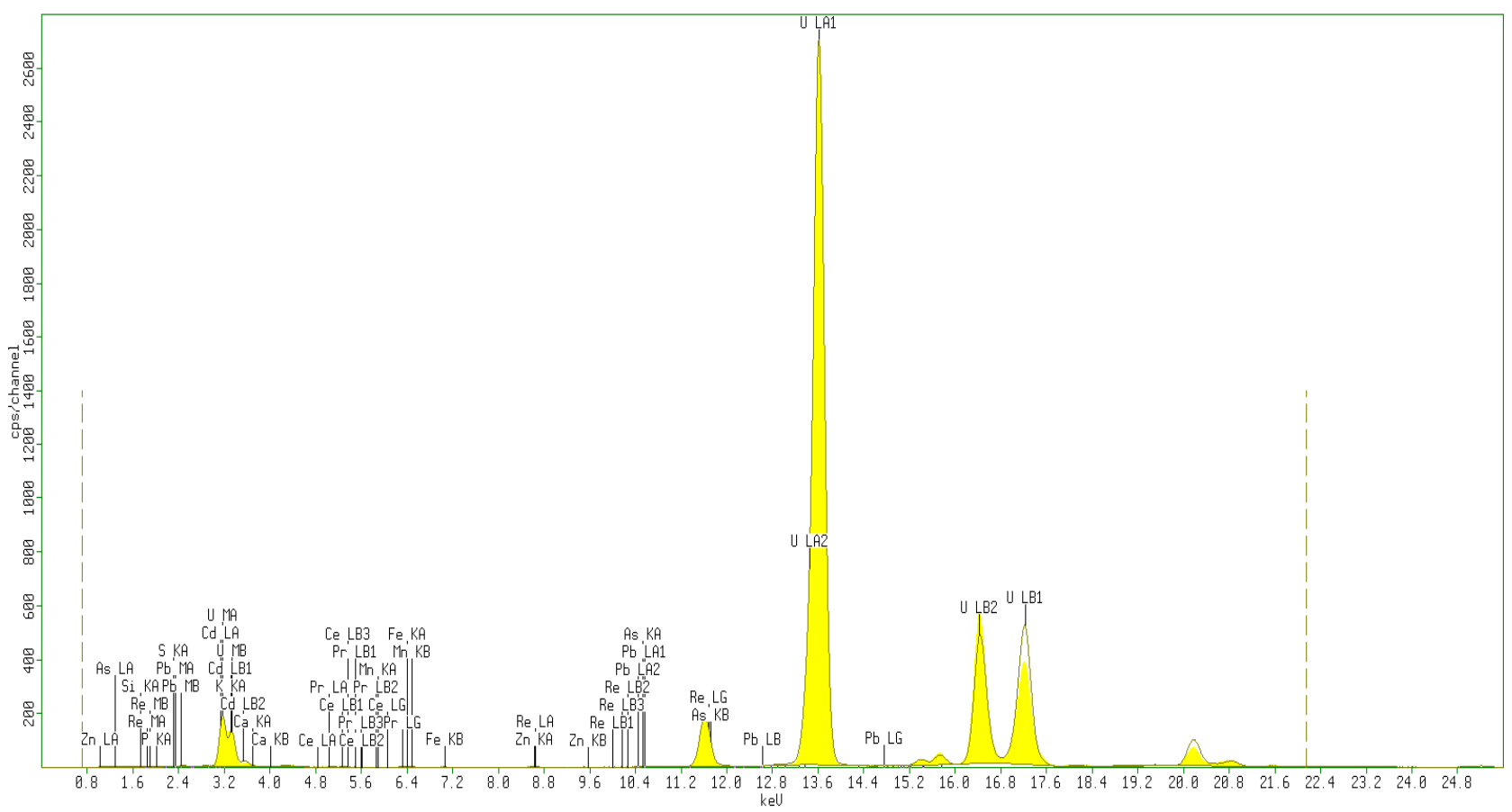

Fig. $3 \mathrm{X}$-ray spectrum of the complex albumin human with $\mathrm{UO}_{2}{ }^{2+}$.

Table 1 Elemental composition of the complex albumin human with $\mathrm{UO}_{2}{ }^{2+}$.

\begin{tabular}{llllllll}
\hline Compound & $\mathrm{C}$ & $\mathrm{H}$ & $\mathrm{O}$ & $\mathrm{N}$ & $\mathrm{S}$ & $\mathrm{P}$ & $\mathrm{U}$ \\
\hline Unit, \% & 33.06 & 0.02 & 22.04 & 19.28 & 0.08 & 0.42 & 0.36 \\
\hline
\end{tabular}




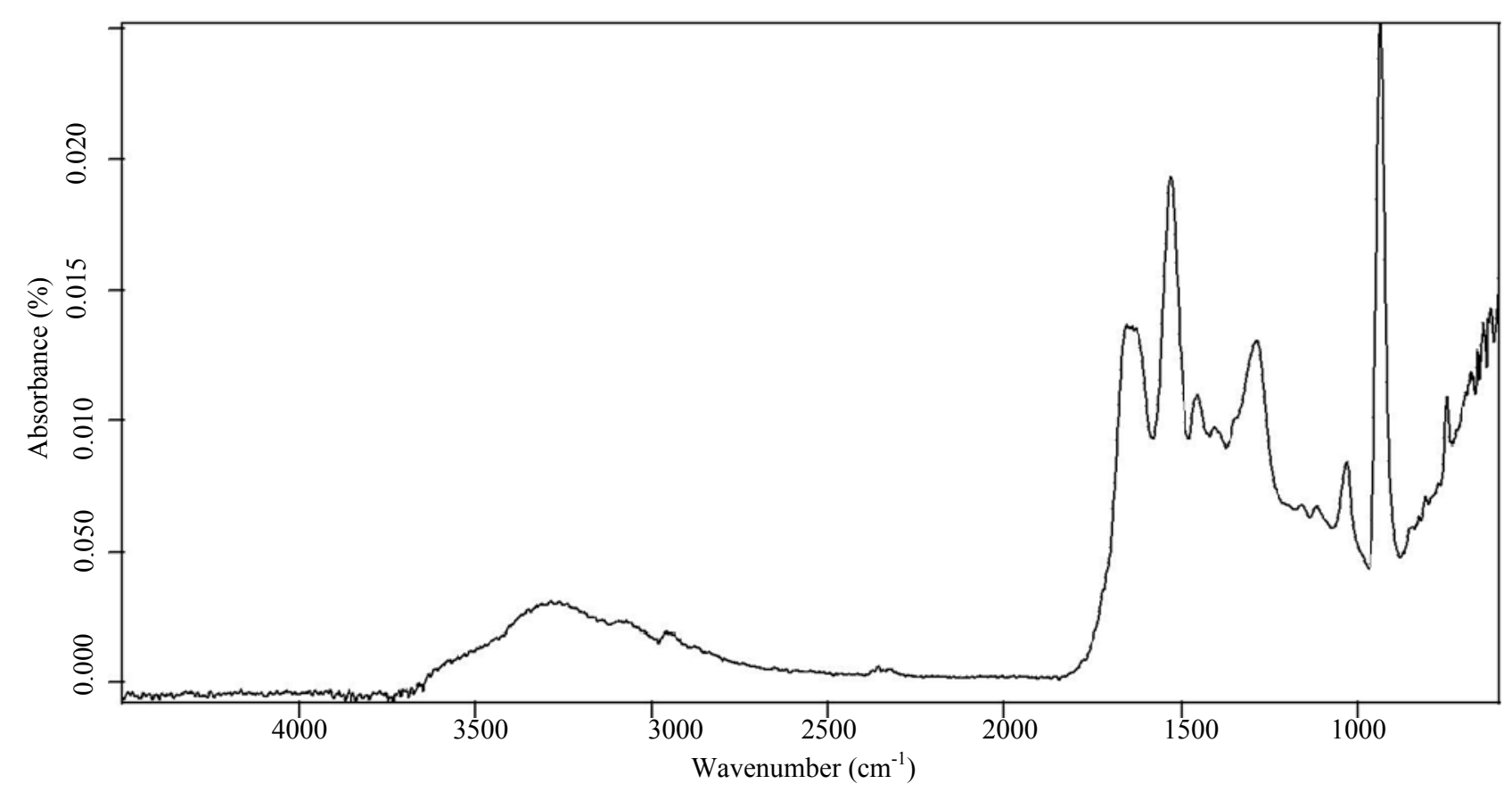

Fig. 4 IR spectrum of the complex albumin human with $\mathrm{UO}_{2}{ }^{2+}$.

\section{Acknowledgments}

The authors would like to thank Lynn C. Francesconi (Hunter College CUNY), Ruben M. Savizky (Columbia University, New York), Peter C. Burns (Notre Dame University, Indiana) and Chistopher L. Cahill (George Washington University) for discussion of the results.

\section{References}

[1] Liu, F., Du, K. J., Fang, Z., You, Y., Wen, G. B., and Lin Y. W. 2007. "Chemical and Biological Insights into Uranium-Induced Apoptosis of Rat Hepatic Cell Line.” Radiat Environ Biophys. 54 (2): 207-16.
[2] Vidaud, C., Gourion-Arsiquaud, S., and Quemeneu, E. 2007. "Structural Consequences of Binding of $\mathrm{UO}_{2}{ }^{2+}$ to Apotransferrin: Can This Protein Account for Entry of Uranium into Human Cells?” Biochem. 46 (8): 2215-26.

[3] Qi, L., Basset, C., and Vidand, C. 2014. "Characterization of $\mathrm{UO}_{2}{ }^{2+}$ Binding to Osteopontin, a Highly Phosphorylated Protein: Insights into Potential Mechanisms of Uranyl Accumulation in Bones." Metallomics 6: 166-76.

[4] Teniz, T. 2012. "Glutamic Acid Containing Supermacroporous Poly(Hydroxyethyl Methacrylate) Cryogel Disks for $\mathrm{UO}_{2}{ }^{2+}$ Removal." Materials Science and Eng. 32 (7): 2052-9.

[5] Yerkin, A., and Valentina, Y. 2015. Spin Chemistry and Magnetic of Uranium-Thorium Catalysts. New York: Scientific \& Academic Publishing, pp. 232. 